\title{
The Effectiveness Of Porpe (Predict, Organize, Rehearse, Practice, And Evaluate) Method To Teach Reading Viewed From Students' Self-Esteem
}

\author{
Alfan Hadi \\ (Dosen STAI AL-AMIN Gersik Kediri Lombok Barat) \\ alvanshine@ymail.com
}

\begin{abstract}
This article reports a study on the implementation of PORPE method to teach reading at the tenth grade students in the academic year of 2012/2013. The objectives of the research are to find out whether: (1) PORPE method is more effective than Direct Instruction Method to teach reading for the tenth grade students; (2) Students who have high self-esteem have better reading skill than those who have low self-esteem; and (3) there is aninteraction between methods of teaching and students' self-esteem to teach reading. This study was categorized as an experimental research. The population of the research was the tenth grade students in the academic year of 2012/2013. The sample of this research was taken by using cluster random sampling. The sample of this research was 60 students covering 30 students of experimental class taught using PORPE method and 30 students of control class taught using Direct Instruction Method. The data collection was done by giving self-esteem questionnaire and reading test (post-test) after eight meetings of treatment. The data analysis was done by applying descriptive and inferential statistics (ANOVA and Tukey HSD test) to test the research hypothesis. The findings of this research are: (1) PORPE Method is more effective than Direct Instruction Method to teach reading at the tenth grade students; (2) The students having high self-esteem have better reading skill than those having low self-esteem; and (3) there is an interaction between teaching methods and self-esteem in teaching reading. The effect of teaching methods on students' reading skill depends on the students' self-esteem level.
\end{abstract}

Keywords: Reading, PORPE Method, Direct Instruction Method, self-esteem, experimental study. 


\section{Introduction}

Reading is one of the important language skills that need to be taught and mastered. Day \& Bamford in John and Ferris (2009: 58) state that many children who were not encouraged to read at home have been "hooked on books" by a caring and creative teacher. ${ }^{1}$ Furthermore, the students do not realize that reading is very important. Freire, 1970 (in Kristin, Leah, and Tenena (2010: 26) phrase "Read the word so that you can read the world" might be used as a slogan to represent the way language knowledge unlocks reading. ${ }^{2}$

Reading is a very complex skill and for this reason it is not surprising to find that some students encounter difficulties in learning to read. Some reading difficulties arouse in the subject of the study, SMA Negeri 2 Labuapi. Westwood (2001: 26) states that there are some factors within the learner or the learner's background, some within the teaching approach, some within the learning environment, and some are possibly related to the working relationship between teacher and students. $3 \mathrm{He}$ also explains that teachers themselves are not particularly skilled in recognizing the cause of a child's learning difficulty. They may know a child is having problems but they are unable to find out why. Teachers often assume that the cause of any learning difficulty lies within the child or his or her family background.

According to Burns, Roe and Ross, "one of the roles of the teacher in Teacher Classroom Behavior Inventory is to difficulty.4 In other word, teacher may think about the kinds of suitable, understanding, and interesting material to teach reading. Furthermore, to enable the students master the reading comprehension skill, teachers should provide materials that are appropriate with the curriculum and find suitable methods in teaching and learning process. One of methods suggested is by using PORPE method, With PORPE, students are involved in (1) predicting potential essay questions to guide subsequent study; (2) organizing key ideas using their own words, structure, and methods; (3) rehearsing the key ideas; (4) practicing

\footnotetext{
${ }^{1}$ John S, H and Dana R, F. 2009. Teaching Readers of English Students, Texts, and Context. New York: Routledge.

2 Kristin, L, Leah, D, M, and Tenena, M, S. 2010. Teaching Reading to English Language Learners. New York: The Guilford Press.

3 Westwood. Peter. 2001. Reading and Learning Difficulties. Australia: The Australian Council for Educational Research Ltd

4 Burns, P. C, Roe B. D and Ross, E. P. (1984).Teaching Reading in Today's Elementary Schools. Boston :Haughton Mifflin Company.
} 
the recall of the key ideas in self-assigned writing tasks; and (5) evaluating the completeness, accuracy, and appropriateness of their written text.

PORPE (Predict, Organize, Rehearse, Practice and Evaluate) is suggested by Simpson and Tahl (1989) from USA. PORPE method is a method to study textbook materials in which the students create and answer essay questions. It can be a timeconsuming process, but it is an excellent means for preparing for essay exams. The first approach in PORPE reading is to predict. To make some prediction, students need to create question that makes use of words such as explain, compare, differentiate, or criticize. After they formulate their own question, they will then organize. Organize involves summarizing the significant terms and key points per chapter or per topic of the material they are reading. After predicting and organizing, it is now time to rehearse the information students have gathered. Reciting aloud and frequently under this step will greatly help they memorize the concept of what they have read. Then, of course, they need to practice by answering their predicted questions using their own words. Finally, students are now ready to evaluate their own work by asking themselves if they answer their predicted question as it should be and whether they have some concrete examples that will support their analysis or explanation. The PORPE aims to give students the details of what they will be reading. After reading using this approach, they will be able to answer the why and how.

The other method that can be applied by teacher is Direct Instruction Method. Arends. "States "Direct instruction is a teacher-centered method that has five steps: establishing set, explanation and/or demonstration, guided practice, feedback, and extended practice. Generally, this model makes the teacher as the center of the teaching and learning process. 5 All the activities in class are under the teacher's direction and are usually done individually. These activities make the students get bored in joining the teaching learning process.

Another factor that also resolves the success of teaching reading comprehension is Self-esteem. Many people have problem with self-esteem and most of them feel loss of their self-esteem in a whole of their life. That's why self-esteem

${ }^{5}$ Arends, R.I. 2001. Learning to Teach. New York:Mcgraw Hill Companies, Inc 
becomes very important to support and make the students believe in their ability to determine the success of teaching reading. Self-esteem is about the individual feeling that may make people believe and feel confident about their ability. People that have high self-esteem believe on their ability and have a realistic hope, even when their wants cannot be realized; they still have positive thinking and can receive it. It also called mental condition or self-psychology that gives strong believing to do something. Self-esteem is the way one feels about oneself, including the degree to which one possesses self-respect and self-acceptance. Self-esteem is the middle of the spectrum in terms of many of the more ordinary problems of living, including difficulties dealing with failure, losses, and other setbacks that are sure to challenge most of us during the course of our lives. Self-esteem is also found at the other end of the continuum because it is often talked about in relation to such things as being mentally healthy, successful, living effectively, and even the "good life." 6

Harmer, states that reading is an exercise dominated by the eyes and the brain. The eyes receive massages and the brain than has to work out the significance of these messages. 7 Harmer, also states that reading is ability to skim a text as if the students were casting their eyes over its surface to get a general idea of what it is about. 8

William (in McDonough and Shaw), usefully classifies reading into getting general information from the text, getting specific information from a text, and for pleasure or for interest. 9 Flesch in Burns, defines reading as getting meaning from certain combination of letters. Teach the child what each letter stands for and he can read.10 According to Anderson, reading is a process of readers combining information from a text and their own background knowledge to build meaning.11 Spears, state that there are eight important reading skills that help learners to read

\footnotetext{
${ }^{6}$ Mruk, J, Christopher. (2003). Self-Esteem Reasearch, Theory, and Practice. New York: Springer Company. 7 Harmer, Jeremy. 2007. How to Teach English. China: Pearson Longman.

8 Harmer, Jeremy. 1991. The practice of English Language Teaching. London and New York: Longman

9 McDonough, Jo. Shaw, Christopher. 1993. Materials and Methods in ELT. United States: Blackwell 10 Burns, Paul C. et. al. 1984.Teaching Reading In Today's Elementary School. Houghton Mifflin Company: Boston

11 Anderson, J, Neil: 2008. Practical English Language Teaching Reading. New York: McGraw Hill Companies
} 
more systematically.12 They comprehend the main idea, determine the author's purpose, distinguish between the main idea and supporting details, make inference, distinguish facts and opinion, analyze structure, annotate, paraphrase, and summarize. Meanwhile, Williams, classifies reading into getting general information from the text, getting specific information from a text, and for pleasure or for interest.13

Based on the definition above, the researcher concludes that reading is interactive process of receiving massages, making inference, skimming a text, comprehending the main idea, determining the author's purpose, distinguishing between the main idea and supporting details, distinguishing facts and opinion, analyzing structure, annotating, paraphrasing and summarizing an information that author writes. Besides, reading comprehension requires a person's ability in reading, finding information, and understanding it.

Interesting teaching method must be applied in order that the students are interested in learning reading. One of the methods which can be used to teach reading is PORPE. According to Simpson. PORPE is a study method that can be used in any content area course that uses the essay exam to measure learning or any test format that encourages higher levels of thinking such as synthesis, application, and evaluation.

Simpson, et al. States PORPE is an independent study method which operationalizes the cognitive and metacognitive processes that effective readers engage in to understand and subsequently learn content area material.14 Simpson in Tsani, states that PORPE method is a method that aims to establish the independence to read on any type of reading material and overcome the weaknesses of students when faced with essay questions. Thus, basically PORPE is a method used to enhance the reader through the metacognitive skills to set goals to read,

12 Spears, Deanne Milan. (2000), Improving Reading Skills, Fourth Edition, San Francisco: McGraw Hill Companies Inc.

13 Williams, D. (1984). Reading in the Language Classroom. London: Macmilan.

14 Simpson, L, Michelle, et al. 1988. An Initial Validation Of A Study Strategy System. Journal of Literacy Research: Sage. 
analyze important aspects in literature, focusing on key ideas, used to make the reading questions, and to monitor and evaluate the learning activities undertaken.15

Based on the theories above, PORPE itself is a method where the students learn to synthesize materials from a text and PORPE is an acronym that stand for the following five steps; Predict, Organize, Rehearse, Practice, and Evaluate.

Another method that can be applied in teaching reading is Direct Instruction method. The direct instruction method was created by Siegfried Engelmann and colleagues in the 1960s at the University of Illinois at Champagne-Urbana.

According to Carmin \& Traub. Direct Instruction is a method to teaching. It is skills-oriented, and the teaching practices imply teacher-directed. It emphasizes the use of small-group, face-to-face instruction by teachers and aides using carefully articulated lessons in which cognitive skills are broken down into small units, sequenced deliberately, and taught explicitly.16 Center on Innovation \& Improvement, defines Direct instruction as instruction led by the teacher, as in "the teacher provided direct instruction in solving these problems." Direct Instruction is an explicit, intensive instructional method that allows students of all abilities to become confident, capable learners.

Direct instruction is described as teacher-directed and fast-paced, using a highly structured presentation of antecedents and consequences (Gersten, Woodward, \& Darch, 17. This meticulously developed, highly scripted method allows constant interactions between the student and the teacher. The responsibility for student learning rests directly on the teacher's design and delivery of instruction. According to Valiathan, Direct Instruction (DI) is used to describe learning material in which the teacher or expert transmits information directly to learners structuring learning time to reach a clearly defined set of objectives as efficiently as possible. ${ }^{18}$

\footnotetext{
${ }^{15}$ Simpson, L, Michelle. 1984. PORPE: A Study Strategy for Learning on the Content Areas. University of Georgia.www.kendallhunt.com/contentarealiteracy/Articles/Simpson.pdf

16 Miller.J. M (2004). Direct Instruction andthe Teaching of Early Reading.wisconsin's teacher-led in surgency. London: Holt, Rinehart and Winston. Inc.

17 Gersten, R., Woodward, J., \&Darch, C. (1986).Direct Instruction: A Research-Based Approach To Curriculum Design And Teaching. Exceptional Children, 53, 17-31; Washington, DC: National Center for Education Evaluation and Regional Assistance, Institute of Education Sciences, U.S. Department of Education. Retrieved from http://ies.ed.gov/ncee.

18 Valiathan. P (2009) Direct Instruction Works (Benefits of Expository E-Learning). Knowledge Platform White Paper. Pp. 1-8. Retrieved april 10, 2010.
} 
Based on the phenomena above, it can be concluded that Direct Instruction method refers to the teacher-directed. Teaching learning process is controlled by the teacher. Generally, all students learn if they are taught and given instruction because the students are under the teacher's control. The teacher's direction and control occur when the teacher selects and directs the learning tasks.

Meanwhile, self-esteem is important for students because it influences the effectiveness of teaching and learning process. Self-esteem is a student's overall evaluation of him- or herself, including feelings of general happiness and satisfaction Harter, self-esteem is a self-judgment of worth or value, based on feelings of efficacy, a sense of interacting effectively with one's own environment Spolsky, 19 Coopersmith, defines self-esteem as the evaluation which individual makes and customarily maintains with regard to himself. It expresses an attitude of approval or disapproval, and indicates the extent to which the individual believes himself to be capable, significant, successful and worthy. 20

According to Blascovich and Tomako, self-esteem refers to an individual's sense of his or her value or worth, or the extent to which a person values, approves or, appreciates, prizes, or likes him or herself. Self-esteem is considered the evaluative component of self-concept, a broader representation of the self that includes cognitive and behavioral aspects as well as evaluative or affective ones. ${ }^{21}$ Based on Soar, self-esteem is a state of mind. It is the way you think and feel about yourself. Having high self-esteem means having feelings of confidence, worthiness and positive regard for yourself. ${ }^{22}$ People with high self-esteem feel good about themselves. They feel a sense of belonging and security. They respect themselves and appreciate others. They tend to be successful in life because they feel confident in taking on challenges and risking failure to achieve what they want. They have more energy for positive pursuits because their energy is not wasted on negative emotions, feelings of inferiority or working hard to take care of or please others at the expense

19 Spolsky, B. 1999 .Concise Encyclopedia of Educational Linguistics. Cambridge: Cambridge University Press

20 Coopersmith, S. 1967. Parental characteristics related to self-esteem. In, The antescedents of selfesteem (chap. 6, pp. 96-117). San Fransisco: Freeman

21 Blascovich J, Tomako J. 1991 Measures of self-esteem. In Robinson JP, Shaver PR, Wrightsman LS (Eds).Measures of Personality and Social Psychological Attitudes. Vol. 1, CA: Academic Press, 1991, pp 115-160.

${ }^{22}$ Soar (2003) Developing SelfEsteem and a Positive Attitude. New York: Guilford Press 
of their own self-care. Based on the theories above, it can be concluded that selfesteem refers to the students' feelings of general happiness and satisfaction, selfjudgment of worth or value, and as the evaluation which individual makes and customarily maintains with regard to himself.

\section{Research Method}

\section{Reseach Design}

The researcher used experimental study because the aim of this study is to investigate the influences or effects of some variables to the subject of the research under controlled circumstance.The researcher involved three variables. The first is independent variable. It is teaching methods, PORPE and Direct Instruction. The second variable is dependent variable. It is students' reading skill. The third is a moderator/ attribute variable. It is students' Self-Esteem.

According to Best and Khan, an experiment involves the comparison of the effects of a particular treatment with that of a different treatment or of no treatment. ${ }^{23}$ In a simple conventional experiment, reference is usually made to an experimental group and to control group. The purpose of an experimental study is to investigate the effectiveness between a certain treatments to experimental class and to control class as the comparison. Thus, the independent variable in experimental research is commonly called as experimental variable or treatment variable. Meanwhile, the dependent variable is known as the outcome variable. Donald, Jacobs, and Sorensen, state that Experimental Researchers study variables, which are characteristics that take on different values across people or things. Experimental research involves a study of the effect of the systematic manipulation of one variable(s) on another variable. The manipulated variable is called the experimental treatment or the independent variable. The observed and measured variable is called the dependent variable. ${ }^{24}$

The population of the research was the tenth grade students of SMA Negeri 2 Labuapi West Lombok in the academic year of 2013/2014 consisting of five classes,

${ }^{23}$ John w. best and James v. Khan. 1995. Research in Education. New Delhi: Prentice hall of India private limited.

24 Donald Ary, Lucy Cheser Jacobs, and Chris Sorensen. 2006. Introduction to Research in Education. Canada: Nelson Education, Ltd. 
they are class A, B, C, D, and E. The samples were two classes, they are class A and class B. Each of classes consisted of 30 students. The samples were taken by using cluster random sampling technique. The experimental class was taught by using PORPE method, while the control class was taught using Direct Instruction method. Then, based on the students' self-esteem, the two classes were divided into two groups (high and low self-esteem).

Self-esteem questionnaire was given to determine students with high selfesteem and low self-esteem. Meanwhile, reading test was given to measure students' reading skill. The data from reading scores were collected after the students got eight times treatment for each group. The data were collected to examine the effects of PORPE method in teaching reading to the tenth grade students in the academic year of $2013 / 2014$.

The researcher conducted the data analysis by using descriptive statistics to measure mean, median, modus, and standard deviation of the data collected. As a requirement for the data analysis, firstly the data were tested using normality and homogeneity test. After measuring normality and homogenity, the researcher analyzed the data using ANOVA (Analysis of Variance) and Tukey test.

\section{Population, Sample, and Sampling}

\section{A. Population}

Population is about the whole of object of study that contains of human, things, animals, plants, conditions, the value of test, or an event as data resources that have characterized in research Hadari Nawawi ${ }^{25}$. According to Gall, Joyce, and Walter, quantitative researches attempt to discover something about a large group of individuals by studying a much smaller group. The larger group that they wish to learn about is called a population. ${ }^{26}$ The population of this study was all of the tenth graders, there were five classes which consisted of 30 students in each class of SMA Negeri 2 Labuapi in the academic year of 2012/2013.

\footnotetext{
${ }^{25}$ Hadari, Nawawi H. 1983. Metode Penelitian Bidang Sosial. Yogyakarta: Gajah Mada University Press.

${ }^{26}$ Gall, D, Meredith.Gall, O, Joyce. And Borg, R, Walter. 2003. Educational Research. United States of America: Pearson Education Inc.
} 


\section{B. Sample}

Sample is a part of numbers and belongs to the population Sugiyono ${ }^{27}$. If the population of group is large and the researcher has no ability to learn about all of the population such as have limited contribution, energy, and time, the researcher can use the sample taken from the population. The sample of the research used was two classes of SMA Negeri 2 Labuapi, at the tenth graders in the academic year of 2012/2013. The researcher took only two classes they were class XA and XB. The experimental group, XA was taught by using PORPE method and XB, the control group was taught by using Direct Instruction method. Furthermore, the students' self-esteem is divided into two groups (high and low self-esteem).

\section{Sampling}

Gay states that sampling is the process of selecting a number of individuals for a study in such a way that the individuals represent the larger group from which they are selected. ${ }^{28}$ The sampling technique that is used in this study is cluster random sampling. Cluster random sampling is a sampling in which group, not individuals, are randomly selected Gay. The researcher took the experimental and control classes by using lottery. First, the researcher wrote the name of classes from $\mathrm{XA}, \mathrm{XB}, \mathrm{XC}, \mathrm{XD}, \mathrm{XE}$ on pieces of paper. Then, there were two pieces of paper taken by lottery, which were class XA and XB. After the two classes were chosen, the researcher did the lottery again to determine whether the experimental and control class. The experimental class is taught using PORPE Method while the control class is taught by Direct Instruction method.

Each class was divided into two groups, students who have high self-esteem and those who have low self-esteem. One of the two classes is taught by PORPE and other class is taught by direct instruction method, so there are four groups:

\section{Research Instrument}

In order to know the level of student's self-esteem, the students are given self-esteem questionnaire. The forms of the items are objective. It is used to make

27 Sugiyono. 2011. Metode penelitian Pendidikan Pendekatan Kuantitatif, Kualitatif, dan R \& D. Bandung: Alfabeta.

28 Gay, L.R. (1992). Competencies for Analysis and Application.Educational Research. New York: Macmillan Publishing Company. 
the students easier to answer. The questionnaire is used to classify students into two groups: the students who have high self-esteem and those who have low self-esteem. The questionnaire consists of statements about students' self-esteem and there are four options chosen in each item. In this case, there is no right or wrong answer because the students' response based on their condition.

The writer used a Likert scale using 4 points scale in which the space between each point on the scale is assumed to be equivalent. It is used to register the extent of agreement or disagreement to a particular statement. Likert scale is created by Dr. Rensis Likert. According to Bertram, Likert scale is psychometric response scale primarily used in questionnaires to obtain participant's preferences or degree of agreement with a statement or set of statements. ${ }^{29}$ Likert scales are a noncomparative scaling technique and are one-dimensional (only measure a single trait) in nature. Respondents are asked to indicate their level of agreement with a given statement by way of an ordinal scale. The items of the questions are in the positive and in negative directions. The four responses consist of strongly agree, agree, disagree, and strongly disagree. For positive statement, the score is from 4 to 1 , while for negative statement, the score is from 1 to 4 .

Furthermore, to know the student's reading skill, the students are given reading test which is designed in the form of objective test. The items of student's self-esteem questionnaire and reading test are made and arranged based on construct and indicators at blue print which are formulated based on reviewing some related theories. The item of both self-esteem questionnaire and reading test are tried out first in order to know the validity and reliability. The valid and reliable items would be used to get the data. Try out of instrument was conducted at the same school, in SMA Negeri 2 Labuapi, at the same graders, but at different class.

To know whether the instrument that is used in this study is valid or not the researcher use content and construct validity. Content validity is the degree to which a test measures an intended content area. To examine the validity of the student's self-esteem questionnaire, the formula that used is as follows:

${ }^{29}$ Bertram, D. 1999. Journal: Likert Scales are The Meaning of Life. http://poincare.matf.bg.ac.rs/.../topicdane-likrt.pdf accessed on March 8, 2012. 


$$
r_{1 t}=\frac{\sum x_{i} \cdot x_{t}}{\sqrt{\left(\sum x_{i}^{2}\right)\left(x_{t}^{2}\right)}}
$$

Where:

$$
\begin{array}{ll}
r_{i t} & : \text { Coefficient of validity } \\
\sum x_{i .} x_{t} & : \text { Total of items variance } \\
\sum x_{i}^{2} & : \text { Total variance of item } \\
\sum x_{t}^{2} & : \text { Total variance }
\end{array}
$$

In which:

$$
s_{t}^{2}=\frac{\sum x_{t}^{2}}{n}
$$

The result of $r_{i t}$ is then compared with $r$ table of product moment at the level of significance $\alpha=0.05$. The item is valid if $r_{o}>r_{t}$ or if $r_{o}$ is higher than $r_{t .}^{30}$

Then, to know the reliability of the student's self-esteem questionnaire, the formula that used is as follows:

$$
r_{k k}=\frac{k}{k-1}\left[1-\frac{\sum s_{i}^{2}}{s_{t}^{2}}\right]
$$

Where:

$$
\begin{array}{ll}
r_{k k}: \text { Coefficient of reliability } \\
\mathrm{k} & : \text { Total of Valid items } \\
\sum s_{i}^{2} & : \text { Total Variance of all items } \\
\sum s_{t}^{2} & : \text { Total Variance }
\end{array}
$$

The result of $r_{0}$ is then compared with $r$ table of product moment at the level of significance $\alpha=0.05$. The questionnaire is reliable if $r_{o}>r_{t}$ or if $r_{o}$ is higher than $r_{t}$

Then, the reading instrument that used is consulted to the experts' judgment and correlated to the curriculum and books used, in this case is the course book for

${ }^{30}$ Ngadiso. 2009. Language Teaching Evaluation Module. Surakarta: UNS Press. 
the senior high school for grade tenth. Furthermore, to know the validity of test, the researcher applied the following formula.

$$
r_{o}=\frac{\overline{X_{i}}-\overline{X_{t}}}{S_{t}} \sqrt{\frac{p_{i}}{q_{i}}}
$$

Where:

$r_{o} \quad$ : Coefficient of validity

$\overline{X_{i}}$ : Mean score of correct answer

$\overline{X_{t}}$ : Mean of total score

$S_{t}:$ Standard deviation of total score

$p_{i}:$ The proportion of correct answers

$q_{i}:$ The proportion of incorrect answers

In which:

$$
S_{t}=\sqrt{\frac{\sum x^{2}}{n}}
$$

The result of $r$ is then compared with $r$ table of product moment at the level of significance $\alpha=0.05$. The item is valid if $r_{0}>r_{t}$ or if $r_{0}$ is higher than $r_{t}$.

Then, to know the reliability of reading test, the formula that used is as follows:

$$
r_{k k}=\frac{k}{k-1}\left[1-\frac{\sum p q}{s_{t}^{2}}\right]
$$

Where:

$$
\begin{array}{ll}
r_{k k} & : \text { Coefficient of reliability } \\
\mathrm{k} & : \text { Total of valid items } \\
\sum p q & : \text { Sums of all item variance } \\
s_{t}^{2} & : \text { Total Variance }
\end{array}
$$

The result of $r_{o}$ is then compared withr table of product moment at the level of significance $\alpha=0.05$. The test is reliable if $r_{o}>r_{t}$ or if $r_{o}$ is higher than $r_{t}$. 


\section{Discussion Of The Findings}

The data analysis is done using multifactor analysis of variance (ANOVA) $2 \mathrm{x}$ 2. $\mathrm{H}_{0}$ is rejected if $\mathrm{Fo}>\mathrm{Ft}$, it means that there is a significant difference and an interaction. If $\mathrm{H}_{0}$ is rejected, the analysis is continued using Tukey test. The ANOVA $2 \times 2$ and Tukey test are described as follows:

1. Summary of Multifactor Analysis of Variance $2 \times 2$

Table 1.1.Multifactor Analysis of Variance

\begin{tabular}{lccccc}
\hline \multicolumn{1}{c}{ Source of Variance } & SS & Df & MS & $\mathbf{F}_{\mathbf{o}}$ & $\mathbf{F}_{\mathbf{t}(\mathbf{0 5})}$ \\
\hline Between columns (The & 141.07 & 1 & 141.07 & 5.15 & 4.02 \\
Teaching Strategies & 256.27 & 1 & 256.7 & 9.35 & \\
Between rows (self-esteem) & 666.67 & 1 & 666.67 & 24.32 & \\
Columns by rows & 1064 & 3 & 354.67 & & \\
(Interaction) & 1534.93 & 56 & $\mathbf{2 7 . 4 1}$ & & \\
Between groups & 5191.69 & 59 & & & \\
Within groups & & & & \\
Total & &
\end{tabular}

The table above shows that:

a. $\mathrm{F}_{\mathrm{o}}$ between columns (5.15) is higher than $\mathrm{F}_{\mathrm{t}(0.05)}(4.02) . \mathrm{H}_{0}$ is rejected and it means the difference between columns is significant. The students' mean of $A_{1}(73)$ is higher than the students' mean of $A_{2}$ (69.99), thus it can be stated that PORPE Method is more effective than Direct Instruction Method to teach reading.

b. $\mathrm{F}_{\mathrm{o}}$ between rows (9.35) is higher than $\mathrm{Ft}(0.05)(4.02) \cdot \mathrm{H}_{0}$ is rejected and it means difference between rows is significant. It can be stated that the difference between the reading skill of the students having high self-esteem and those having low self-esteem is significant. The students' mean of $B_{1}$ (73.53) is higher than the students' mean of B2 (69.40). Hence, the students who have high level of self-esteem have better reading skill than the students who have low selfesteem.

c. $\mathrm{F}_{\mathrm{o}}$ interaction (24.32) is higher than $\mathrm{F}_{\mathrm{t}}\left({ }_{0.05}\right)(4.02) \cdot \mathrm{H}_{0}$ is rejected and it can be stated that there is interaction effect between the two variables, the teaching methods and the degree of self-esteem on the reading skill. It means that the effect of the teaching methods used on the reading skill depends on the student's' degree or level of self-esteem. 
2. Summary of Tuckey Test

The pattern of $q$ is found by dividing the difference between the means by the square root of the ratio of the within group variation and the sample size. The following is the result of tuckey test:

Table 1.2. Summary of Tukey Test

\begin{tabular}{ccccc}
\hline $\begin{array}{c}\text { Between } \\
\text { Group }\end{array}$ & $\mathrm{q}_{\mathrm{o}}$ & $\mathrm{q}_{\mathrm{t}}$ & Status & Meaning \\
\hline $\mathrm{A}_{1}-\mathrm{A}_{2}$ & 3.21 & 2.89 & Significant & $\mathrm{A}_{1} \neq \mathrm{A}_{2}$ \\
$\mathrm{~B}_{1}-\mathrm{B}_{2}$ & 4.32 & 2.89 & Significant & $\mathrm{B}_{1} \neq \mathrm{B}_{2}$ \\
$\mathrm{~A}_{1} \mathrm{~B}_{1}-\mathrm{A}_{2} \mathrm{~B}_{1}$ & 10.18 & 3.01 & Significant & $\mathrm{A}_{1} \mathrm{~B}_{1} \neq \mathrm{A}_{1} \mathrm{~B}_{1}$ \\
$\mathrm{~A}_{1} \mathrm{~B}_{2-} \mathrm{A}_{2} \mathrm{~B}_{2}$ & 3.77 & 3.01 & Significant & $\mathrm{A}_{1} \mathrm{~B}_{2} \neq \mathrm{A}_{2} \mathrm{~B}_{2}$ \\
\hline
\end{tabular}

a. Because $\mathrm{q}_{\mathrm{o}}$ between columns $\mathrm{A}_{1} \mathrm{~A}_{2}$ (3.21) is higher than $\mathrm{q}_{\mathrm{t}(0.05)}(2.89)$, the difference between columns is significant. The students' mean of $A_{1}(73)$ is higher than the students' mean of $A_{2}$ (69.93). It can be inferred that teaching reading using PORPE Method at the tenth graders of SMAN 2 Labuapi Lombok Barat is more effective than teaching reading using Direct Instruction Method.

b. Because $\mathrm{q}_{\mathrm{o}}$ between rows $\mathrm{B}_{1} \mathrm{~B}_{2}$ (4.32) is higher than $\mathrm{q}_{\mathrm{t}(0.05)}(2.89)$, it can be concluded that the students who have high self-esteem and those who have low self-esteem are significantly different in their reading skill. Hence, $\mathrm{B}_{1}(73.53)$ is higher than $\mathrm{B}_{2}$ (69.40), it can be stated that the students having high self-esteem have better reading skill and those having low self-esteem.

c. Because $\mathrm{q}_{\mathrm{o}}$ between cells $\left(\mathrm{A}_{1} \mathrm{~B}_{1}\right.$ and $\left.\mathrm{A}_{2} \mathrm{~B}_{1}\right)(10.18)$ is higher than $\mathrm{q}_{\mathrm{t}}(0.05)$ (3.01), the students who have high self-esteem who are taught by using PORPE Method are significantly different in reading skill from the students who have low self-esteem who are taught by using Direct Instruction Method. The mean score of students having high self-esteem $A_{1} B_{1}$ (78.40) is higher than that of those who have low self-esteem $A_{2} B_{1}(68.67)$, so PORPE Method is more effective than Direct Instruction Method to teach reading for the students having high self-esteem.

d. Because $\mathrm{q}_{0}$ between two cells $\left(\mathrm{A}_{1} \mathrm{~B}_{2}\right.$ and $\left.\mathrm{A}_{2} \mathrm{~B}_{2}\right)$ (3.77) is higher than $\mathrm{q}_{t}(0.05)$ (3.01), Direct Instruction Method differs significantly from PORPE Method to teach reading for students who have low self-esteem. The mean score of students having low self-esteem who are taught by Direct Instruction Method (71.20) is higher than those who are taught by using PORPE Method (67.60), thus Direct Instruction 
Method is more effective than PORPE Method for teaching reading for students having low self-esteem.

Based on the result of point 3 and 4, PORPE method is more effective than Direct Instruction method to teach reading for students who have high self-esteem and Direct Instruction Method is more effective than PORPE method to teach reading for students who have low self-esteem. Therefore, it can be concluded that there is an interaction between teaching methods and students' self-esteem in teaching reading.

\section{Conclusion and Suggestion}

Based on the information obtained from the discussion in the previous chapter, it can be concluded that: (1) PORPE method is more effective than Direct Instruction method to teach reading. (2) The students having high self-esteem have better reading skill than low self-esteem. (3) There is the interaction between the two variables, types of teaching method and the level of self-esteem. The interaction in the teaching reading itself can be elaborated as follows: (a) PORPE is effective for students who have high self-esteem and (b) Direct Instruction is effective for students who have low self-esteem.

The first conclusion states that PORPE method is more effective than Direct Instruction method to teach reading, it is implied that PORPE method is effective to teach reading comprehension. Therefore, it is good to be applied in teaching reading comprehension, especially in the tenth grade students of senior high school. The teachers need to use appropriate method that suits with the students' needs in teaching reading. One of them is using PORPE method in the teaching and learning process of reading since it is effective to improve the students' reading comprehension.

The second conclusion is that the students having high self-esteem have better reading skill than low self-esteem. There are some implications and suggestions addressed to parents, environment, and English teachers. Self-esteem is a term used in psychology to reflect a person's overall emotional evaluation of his or her own worth. It is a judgment of oneself as well as an attitude toward the self. Parents, more than anyone else can promote their child's self-esteem. It is not a particularly difficult thing to do. In fact, most parents do it without even realizing that their words and 
actions have great impact on how their child or teenager feels about himself. Parents often become involved in their children's education through homework. Whether children do homework at home, complete it in after school programs or work on it during the school day, homework can be a powerful tool for letting parents and other adults know what the child is learning, giving children and parents a reason to talk about what's going on at school, and giving teachers an opportunity to hear from parents about children's learning.

The students having low self-esteem will often withhold themselves from interactions with others, becoming uninterested in their academics and extracurricular activities. Self-esteem strategies do not require financial costs or a budget, but rather the sensitivity, respect, and caring of teachers. Self-esteem strategies involve helping students feel they belong and are welcome in the school setting, providing them with responsibilities through which they perceive themselves as contributing and making a difference (ex; tutoring younger children, helping to take care of school plants, etc), offering them opportunities to make choices and decision and solve problems, and communicating encouragement and positive feedback. Furthermore, school can provide activities which can improve students' self-esteem.

Teachers have a very significant, lifelong impact on all of their students. This impact involves not only the teaching of particular academic skills, but as importantly, the fostering of student self-esteem. Reinforcing self-esteem in the classroom is associated with increased motivation and learning. Teacher needs to offer them opportunities to make choices and decisions and solve problems, and communicating encouragement and positive feedback. While these kinds of positive interventions are important for all students, they are particularly relevant for students who find learning problematic. Many of the teachers' negative memories captured situations in which they felt that teachers demeaned, belittled, or accused them of being disruptive as they struggled to understand what was being taught. Children with learning difficulties are especially vulnerable to this kind of treatment and unfortunately, even today, continue to hear accusations that they are lazy and unmotivated or that they should pay closer attention so that they wouldn't have to ask so many questions. Teachers must constantly communicate to students that 
mistakes are part of the learning process and that no student should ever feel embarrassed to ask questions if they do not understand something. To minimize student fear of making mistakes and feeling humiliated, the researcher hope that during the first or second day of the new school year teachers ask students, "who feels they will probably made a mistake in class this year or not understand something the first time?" and before anyone can respond, teachers raise their own hands. Teachers can then ask the class why they thought this question about mistakes was posed and use student replies as a launching pad to discuss how fears of not knowing something and making mistakes interfere with offering opinions and answers, and learning.

Based on the last conclusion, the researcher describes the implication and suggestion constructed for English teachers, school and other researchers. Choosing methods of teaching precisely contributes positive impact to the students' achievement in the end of the teaching and learning process. It is undeniable that teaching method which is used by the teacher in the class provides a big influence for the success of the teaching and learning process. Self-esteem becomes one of the important considerations in teaching reading because students are able to read a text and also other tasks well if they have belief that they can do. Thus, teachers should know whether the selected teaching method can make and facilitate the students having high and low self-esteem to mastered reading comprehension. It is better for the teachers to use students centered to teach students having high self-esteem while teacher-centered for the students having low self-esteem.

Since self-esteem considered as one of the psychological aspects to have a good reading skill and any other subjects, school as the official institution for education should pay more attention on students' self-esteem level. In this case, school should involve actively testing the students' self-esteem level. The self-esteem test instrument can be designed by capable teachers or psychologists. It can be conducted before the process of teaching and learning reading done in the classroom. By taking a look at the result of students' self-esteem level, school can decide what kinds of teaching method which is appropriate to teach reading.

The result of this study which shows the interaction between teaching methods and self-esteem can be as an additional reference and as the starting point to 
continue the next study. The result of this research is expected that it can encourage other researchers to conduct further study dealing with PORPE method in other skill areas such as listening, speaking, or writing and It also useful for other researchers who may plan to have the similar research viewed from any different psychological point of view besides self-esteem which may have correlation with students' reading like creativity, intelligence, personality, risk-taking, self-concept etc.

\section{References}

Anderson, J, Neil: 2008. Practical English Language Teaching Reading. New York: McGraw Hill Companies

Arends, R.I. 2001. Learning to Teach. New York:Mcgraw Hill Companies, Inc

Beatrice. S. M and Jefferies. L. 1996. More Reading Power.San Francisco State University:: Addison-Wesley Company, Inc.

Bean, T.W., (2007). Writing across the curriculum. In Searfoss, L. W., Readence, J. E., \&Mallette, M. H. Helping children learn to read (5th ed., pp. 277-309). Boston, MA: Allyn and Bacon.

Bertram, D. 1999. Journal: Likert Scales are The Meaning of Life. http://poincare.matf.bg.ac.rs/.../topic-dane-likrt.pdf accessed on March 8, 2012.

Blascovich J, Tomako J. 1991 Measures of self-esteem. In Robinson JP, Shaver PR, Wrightsman LS (Eds).Measures of Personality and Social Psychological Attitudes. Vol. 1, CA: Academic Press, 1991, pp 115-160.

Brown, H, Douglas. 2007. Principles of Language Learning and Teaching. United States of America. Pearson Education, Inc.

Brown 2004.Effective Teaching In Higher Education. London and New year.

Brown, Jonathon, D. 2002. Self-esteem; It's Not What You Think. Seattle; University of Washington

Budiyono.(2003). MetodePenelitianPendidikan. Surakarta: UNS Press.

Burns, P. C, Roe B. D and Ross, E. P. (1984).Teaching Reading in Today's Elementary Schools. Boston : Haughton Mifflin Company.

Burns, Paul C. et. al. 1984.Teaching Reading In Today's Elementary School. Houghton Mifflin Company: Boston 
Burns, Paul C. et. al. 1984.Teaching Reading In Today's Elementary School. Houghton Mifflin Company: Boston

Carnine. D. W. Direct Instruction Method. Great Britain: Pearson Education Inc.

Center On Innovation \& Improvement (2008). Five Meanings Of Direct Instruction

Chesla. Elizabeth. 2001. Reading Comprehension Success. New York: Learning Express, LLC

Cohen, T, Marisa. 2008. The Effect of Direct Instruction versus Discovery Learning on the Understanding of Science Lessons by Second Grade Students. The Graduate Center, City University of New York

Cook, L. K., \& Mayer, R. E. (1993). Reading strategies training for meaningful learning from prose. In Pressley, M., and Levin, J. R. (Eds.), Cognitive strategy research: Educational applications (pp. 87-131). New York: Springer-Verlag.

Coopersmith, S. 1967. Parental characteristics related to self-esteem. In, The antescedents of self-esteem (chap. 6, pp. 96-117). San Fransisco: Freeman

Corsini, Raymond J. 1994. Encyclopedia of Psychology. 2nded. New York: John Wiley \& Sons.

Cruickshank, et al. (1999). The Act of Teaching. New York: McGraw-Hill College.

Elliott, Stephen N, et.al. 2000. Educational Psychology: Effective Teaching, Effecting Learning. $3^{\text {rd }}$ ed. Boston: McGraw-Hill.

Emler, Nicholas. 2001. Self-Esteem the Costs and Causes of Low Self-Worth. New York: Macmillan Publishing Company.

Feldman, Robert S. 2005. Understanding Psychology. 7th ed. New York: The McGrawHill Companies, Inc.

Gay, L.R. (1992). Competencies for Analysis and Application.Educational Research. New York: Macmillan Publishing Company.

Gersten, R., Woodward, J., \&Darch, C. (1986).Direct Instruction: A Research-Based Approach To Curriculum Design And Teaching. Exceptional Children, 53, 17-31; Washington, DC: National Center for Education Evaluation and Regional Assistance, Institute of Education Sciences, U.S. Department of Education. Retrieved from http://ies.ed.gov/ncee.

Harter, S. (1999).The construction of the self: A developmental perspective. New York: Guilford Press

Harmer, Jeremy. 2007. How to Teach English. China: Pearson Longman. 
Harmer, Jeremy. 1991. The practice of English Language Teaching. London and New York: Longman

Hasanah, Yusnita. 2010. The Implementation of PORPE Method to Increase Student's Ability in Comprehending Reading Text at SMPN 25 PekanBaru. University of PekanBaru.Unpublished thesis.

Hasriani.(2006). The Correlation between Reading Speed and Reading Comprehension; University of Indonesia: Unpublished thesis.

Haynes, Judie. Zacarian, Debbie. (2010). Teaching English Language Learners. Virginia: ASCD

Hidayah, N. (2007). The Use Of Beauty And The Beast Illustrated Version As Narrative Reading Material (An Experimental Study at Eighth Grade Students of SMP Negeri 1 Mungkid in the Academic Year 2006/2007). A Thesis. Semarang: Semarang State University.

Jennings. et. Al. 2001 Study Skills Project. General Science. Newton's First Law pp. 268 269

John S, H and Dana R, F. 2009. Teaching Readers of English Students, Texts, and Context. New York: Routledge.

Kristin, L, Leah, D, M, and Tenena, M, S. 2010. Teaching Reading to English Language Learners. New York: The Guilford Press.

Kucer, Stephen, B. 2005. Dimensions of Literacy. London: Lawrence Erlbaum Associates

Langer, J. A. (2000). Guidelines for teaching middle and high school students to read and write well. New York: Longman

Landsberger (1996).The Study Guides and Strategies web site created and maintained University of St. Thomas (UST), St. Paul, Minnesota.

Leary, Mark R. "Making Sense of Self-Esteem." American Psychological Society 8.1 (1999): 32-35. JSTOR.Web. 14 Sep. 2011.

Loree J. Hisken. (2011). The Correlation Between Self-Esteem And Student Reading Ability, Reading Level, And Academic Achievement.Warrensburg; University of Central Missouri

Matthews. W (1998).Self-Esteem. Department of Family and Consumer Sciences North Carolina Cooperative Extension Service North Carolina State University

McDonough, Jo. Shaw, Christopher. 1993. Materials and Methods in ELT. New York: Blackwell 
Miller,Debbie.2006. Reading with Meaning. Portland, Maine: Stenhouse Publishers

Miller.J. M (2004). Direct Instruction andthe Teaching of Early Reading.wisconsin's teacherled in surgency. London: Holt, Rinehart and Winston. Inc.

Mruk, J, Christopher. (2006). Self-Esteem Reasearch, Theory, and Practice. New York: Springer Company.

National Institute of Child Health and Human Development.(2000). Report of the National Reading Panel. Teaching children to read: An evidence-based assessment of the scientific research literature on reading and its implications for reading instruction $\mathrm{NIH}$ Publication No. 00-4769). Washington, DC: U.S. Government Printing Office.

Ngadiso. 2007. Language Teaching Evaluation Module. Surakarta: UNS Press

Ngovo, B. (1999, Winter99). Study Strategies for Narrative Texts: PORPE and Annotation. Journal of Developmental Education, 23(2), 24.Retrieved January 21, 2009, from Academic Search Complete database.

Nunan, David. 1992. Research Methods in Language Learning. New York: Cambridge University Press.

Nunan, David. 2003. Practical English Language Teaching. New York: McGraw- Hill.

Nunan, David. 1995. Language Teaching Methodology. Great Britain: Prentice Hall Europe.

Peter J. Burke, et al. Theory of Self-Esteem. Journal of Personality 59:473-505. Washington State University.

Powell, J. 2006. Self-Esteem.Minnesota: Smart Apple Media.

Purwanto. 2010. StatistikaUntukPenelitian. Surakarta: PustakaBelajar.

Reading Method:PORPE. 2007. http://www.arc.sbc.edu/porpe.html

Rivers, W, and M, Temperley. (1978). A Practical Guide to the Teaching of English as Foreign or Second Language. New York: Oxford University Press.

Rosenshine, B. 1983.Teaching Functions in Instructional Programs.Elementary School Journal 83, , 335-350.

Simanjuntak, Edithia. 1987. Developing Reading Skill for EFL Students. Jakarta: DepartemenPendidikandanKebudayaan.

Simpson, L, Michelle. 1984. PORPE: A Study Strategy for Learning on the Content Areas. University

of Georgia.www.kendallhunt.com/contentarealiteracy/Articles/Simpson.pdf 
Simpson, L, Michelle, et al. 1988. An Initial Validation ofa Study Strategy System.Journal of Reading Behaviour, Volume XX, No. 2.http://jlr.sagepub.com/content/2012/149

Snow, Chaterine. 2002. Reading for understanding. Pittsburgh: Rand

Soar (2003) Developing Self Esteem and a Positive Attitude. New York: Guilford Press

Spears, Deanne Milan. (2000), Improving Reading Skills, Fourth Edition, San Francisco: McGraw Hill Companies Inc.

Spolsky, B. 1999 .Concise Encyclopedia of Educational Linguistics. Cambridge: Cambridge University Press

SRA. 2005. Direct Instruction Methodology. McGraw Hill

Sutton \&Sutton 1997 Administrative Science Quarterly. London: Rand Ltd

Vacca, et al. 1991.Reading and Learning to Read. New York: Harper Collins

Publishers.

Valiathan. P (2009) Direct Instruction Works (Benefits of Expository E-Learning). Knowledge Platform White Paper. Pp. 1-8. Retrieved april 10, 2010.

Vygotsky, L. S. (1962). Thought and language. Cambridge, MA: MIT Press.

Wallace, Catherine. 1992. Reading. New York: Oxford University Press.

Westwood. Peter. 2001. Reading and Learning Difficulties. Melbourne: The Australian Council for Educational Research Ltd

Williams, D. (1984). Reading in the Language Classroom. London: Macmilan. 